\title{
HUBUNGAN MOTIVASI DENGAN PENDAPATAN PETANI CABAI MERAH YANG BERMITRA DENGAN BINAMITRA HORTIKULTURA MULTIAGROMAKMUR DI KECAMATAN AMBULU KABUPATEN JEMBER, JAWA TIMUR
}

\author{
THE CORRELATION BETWEEN MOTIVATION WITH \\ CHILI PEPPER FARMER'S INCOME IN PARTNERSHIP WITH \\ BINAMITRA HORTIKULTURAMULTIAGRO MAKMUR IN AMBULU \\ SUB DISTRICT, JEMBER REGENCY, EAST JAVA
}

\author{
Wilda Ayu Damayanti, Sri Subekti, Sudarko \\ Program Studi Agribisnis Fakultas Pertanian Universitas Jember \\ email: wildaayudamayanti@gmil.com
}

\begin{abstract}
Chili pepper has the characteristics of rapid rot and large shrinkage that can cause production risks. Fluctuating prices of chili pepper also makes high-risk of chili pepper farming. Farmers' strategy to overcome them is to build a partnership with Binamitra Hortikultura Multiagro Makmur. Market guarantees and prices and facilities provided make farmers more motivated to cultivate chili pepper. The existence of farmer motivation in chili pepper farming is able to increase productivity so that can increase income of chili pepper farmers. The purpose of this research discusses: partnership pattern between chili's farmers and Binamitra Multiagro Makmur, correlation between farmer's characteristic with farmer's motivation, and correlation between motivation with farmer income of chili pepper farmers that are partnered with Binamitra Hortikultura Multiagro Makmur Ambulu District Jember Regency, East Java. Sampling method is total sampling, that is chili pepper farmers who are partnered with Binamitra Hortikultura Multiagro Makmur with a total number of 32 farmers. Data collection was done by interview, observation, and documentation study. The research method that is used are descriptive and analytical analysis. Data analysis to determine the correlation between farmer's characteristic with farmer's motivation and correlation between motivation with income of chili pepper farmers uses Rank Spearman. The results were: (1) the sub-contract partnership pattern were used by farmers and Binamitra Hortikultura Multiagro Makmur, (2) there is a significant correlation between age, formal education, and cropland area with farmer motivation while the number of family dependents and experience have acorrelation that is not significant with farmer motivation, and (3) there is a significant correlation between motivation and income of chili pepper farmers.
\end{abstract}

Key Word: farmer's characteristic, income, motivation, rank spearman 


\title{
Damayanti, Subekti, Sudarko, karakteristik petani,,,
}

\begin{abstract}
Abstrak
Cabai merah mempunyai karakteristik cepat busuk dan susut besar sehingga dapat menimbulkan risiko produksi. Fluktuatif harga cabai merah juga membuat usahatani cabai merah berisiko tinggi. Strategi yang dijalankan petani untuk mengatasinya adalah menjalin kemitraan dengan Binamitra Hortikultura Multiagro Makmur. Jaminan pasar dan harga serta fasilitas-fasilitas yang diberikan membuat petani lebih termotivasi untuk berusahatani cabai merah. Adanya motivasi petani untuk usahatani cabai merah mampu meningkatkan produktivitas sehingga dapat meningkatkan pendapatan petani cabai merah.Tujuan penelitian membahas: pola kemitraan antara petani cabai merah dengan Binamitra Hortikultura Multiagro Makmur, hubungan antara karakteristik petani dengan motivasi petani, dan hubungan antara motivasi dengan pendapatan petani cabai merah yang bermitra dengan Binamitra Hortikultura Multiagro Makmurdi Kecamatan Ambulu Kabupaten Jember, Jawa Timur. Metode pengambilan sampel adalah total sampling, yaitu petani cabai merah yang bermitra dengan Binamitra Hortikultura Multiagro Makmur sejumlah 32 petani. Pengumpulan data dilakukan dengan cara wawancara, observasi, dan studi dokumentasi. Metode penelitian yang digunakan yaitu analisis deskriptif dan analitis. Analisis data untuk mengetahui hubungan antara karakteristik petani dengan motivasi danhubungan antara motivasi dengan pendapatan petani cabai merah menggunakan Rank Spearman. Hasil penelitian menunjukkan bahwa (1) pola kemitraan yang terjalin antara petani cabai merah dengan Binamitra Hortikultura Multiagro Makmur adalah pola subkontrak, (2) terdapat hubungan secara signifikan antara umur, pendidikan formal, dan luas penguasaan lahan dengan motivasi petani sedangkan jumlah tanggungan keluarga dan pengalaman usahatani terdapat hubungan secara tidak signifikan dengan motivasi petani, dan (3) terdapat hubungan secara signifikan antara motivasi dengan pendapatan petani cabai merah.
\end{abstract}

Key Word: karakteristik petani, motivasi, pendapatan, rankspearman

\section{PENDAHULUAN}

Komoditas hortikultura merupakan salah satu sumber akselerasi pertumbuhan sektor pertanian karena sifat permintaannya yang elastis terhadap pendapatan. Seiring dengan laju pertambahan jumlah penduduk, yang dibarengi dengan peningkatan pendapatan, dan berkembangnya pusat kota-industriwisata, serta liberalisasi perdagangan merupakan faktor potensial bagi peningkatan permintaan produk hortikultura. Namun demikian potensi pasar tersebut belum mampu dimanfaatkan para pelaku agribisnis hortikultura secara optimal (Indraningsih et al., 2004). Indonesia dengan potensi sumber daya lahan dan agroklimat yang beragam berpeluang untuk mengembangkan berbagai tanaman hortikultura tropis, yang mencakup 323 jenis komoditas(Dirjen Hortikultura, 2012).Salah satu komoditas hortikultura adalah cabai merah. Cabai merah mempunyai karakteristik cepat busuk, rusak, dan susut 


\section{Jurnal Agritexts Volume 41 Nomer 2 Oktober 2017}

besar merupakan masalah yang dapat menimbulkan risiko produksi dan harga. Harga yang fluktuatif membuat usahatani cabai merah menjadi berisiko tinggi. Selain itu, faktor cuaca dan gangguan organisme menjadi faktor yang perlu diperhatikan padausahatani cabai merah. Jika ditinjau dari segi permintaan, tanaman cabaimerah mempunyai arti penting bagi keperluan sehari-hari sehingga cabai merah mempunyai prospek untuk dibudidayakan.Menurut Setiadi (2000), permintaan cabai merah cukup tinggi dan relatifkontinyu. Waktu yangdibutuhkan untuk penanaman juga relatif singkat,dan adanya berbagai alternatif teknologi yangtersedia serta relatif mudahnya teknologi tersebutdiadopsi petani merupakan rangsangan tersendiri bagi petani (Hutabarat dan Rahmanto 2002). Hal tersebut akan memotivasi petani untuk berusaha tani cabai merah lebih giat lagi.

Kabupaten Jember adalah daerah penghasil tanaman hortikultura, salah satunya cabai merah. Kecamatan Ambulu menjadi salah satu sentra daerah penghasil cabai merah. Produksi cabai merah di Kecamatan Ambulu sebanyak 12.849 kw dengan luas panen 124 ha sehingga produktivitasnya sebesar $103.62 \mathrm{kw} / \mathrm{ha}$.Hal tersebut dilihat dari hasil produksi cabai merah tahun 2015pada Tabel 1.

Tabel 1. Data Luas Panen, Produksi, dan Produktivitas Berdasarkan Kecamatan di Kabupaten Jember Tahun 2015

\begin{tabular}{lrrr}
\hline \multicolumn{1}{c}{ Kecamatan } & Luas Panen (ha) & Produksi (kw) & Produktivitas (kw/ha) \\
\hline Kencong & 21 & 1.192 & 56,76 \\
Gumukmas & 57 & 6.226 & 109,23 \\
Puger & 6 & 670 & 111,67 \\
Wuluhan & 269 & 28.510 & 105,99 \\
Ambulu & $\mathbf{1 2 4}$ & $\mathbf{1 2 . 8 4 9}$ & $\mathbf{1 0 3 , 6 2}$ \\
Tempurejo & 33 & 3.076 & 93,21 \\
Silo & 5 & 360 & 72,00 \\
Mayang & 9 & 670 & 74,44 \\
Mumbulsari & 6 & 397 & 66,17 \\
Jenggawah & 20 & 1.793 & 89,65 \\
\hline Sumber: Dinas Pertanian Kabupaten Jember, 2016 & &
\end{tabular}

Petani cabai merah di Kecamatan Ambulu sebagian besar menjual hasil produksinya kepada perusahaan mitra. Petani cabai merah yang akan menjual hasil produksinya kepada perusahaan mitra harus berada dalam suatu wadah, yaitu, Binamitra Hortikultura Multiagro Makmur. Kemitraan merupakan strategi bisnis yang dilakukan oleh dua pihak atau lebih, dalam jangka waktu tertentu, untuk 


\section{Damayanti, Subekti, Sudarko, karakteristik petani,נ,}

meraih keuntungan bersama, dengan prinsip saling membutuhkan dan saling membesarkan. (Sumardjo et al., 2004). Menurut penelitian Ningtias (2015), terdapat perbedaan pendapatan antara petani cabai merah yang bermitra dan tidak bermitra. Petani yang bermitra lebih terjamin harga dan pasar sehingga petani lebih memilih untuk bermitra. Kemudahan - kemudahan tersebut menggerakkan petani untuk lebih termotivasi berusahatani cabai merah.

Motivasi merupakan hal yang berperan penting dalam meningkatkan suatu efektivitas kerja, karena orang yang mempunyai motivasi yang tinggi akan berusaha dengan sekuat tenaga supaya pekerjaannya dapat berhasil dengan sebaikbaiknya, hingga akan membentuk suatu peningkatan produktivitas kerja (Moekijat, 1999).Menurut Siagian (2002), teori harapan yang dikemukakan oleh Victor Vroom menekankan bahwa kekuatan kecenderungan berperilaku tertentu tergantung pada kuatnya harapa, bahwaperilaku tersebut akan diikuti oleh keluaran tertentu dan oleh kuatnya daya tarik keluaran itu bagi orang yang bersangkutan. Adanya motivasi petani dalam usahatani cabai merah mampu meningkatkan produktivitas sehingga dapat meningkatkan pendapatan petani cabai merah.
Motivasi dibentuk oleh karakteristik sosial ekonomi yang bersumber dari dalam individu yang meliputi (1) umur, (2) pendidikan formal, (3) pendidikan non formal, (4) pengalaman, (5) pendapatan, dan (6) luas lahan (Hartatik dalam Prasilia, 2013). Motivasi dalam melakukan kegiatan pertanian berpengaruh pada keputusan petani yang akhirnya mempengaruhi keadaan motivasi ekonomi. Status sosial ekonomi berhubungan dengan motivasi ekonomi, baik status tindakan sosial ekonomi secara langsung dan aktif maupun sebagai pelengkap faktor yang mempengaruhi kondisi motivasi yang terkait dengan pendapatan (Singh dalam Prasilia, 2013).

Faktor-faktor yang berhubungan dengan motivasi petani bawang merah menurut Prasilia (2013) adalah karakteristik umur, pendidikan formal dan non formal, pendapatan, luas penguasaan lahan, pengalaman berusahatani, kekosmopolitan, dan keaktifan keanggotaan petani memiliki hubungan dengan motivasi petani. Hasil penelitian Primadesi (2010) menyatakan bahwa terdapat hubungan yang sangat signifikan antara pendidikan formal, pendidikan non formal, luas lahan, dan lingkungan sosial dengan motivasi petani buah naga serta tidak terdapat hubungan yang signifikan antara umur, lingkungan ekonomi, 


\section{Jurnal Agritexts Volume 41 Nomer 2 Oktober 2017}

dan kebijakan pemerintah dengan motivasi petani buah naga di Kecamatan Bendosari Kabupaten Sukoharjo. Menurut Fauzi (2009), terdapat hubungan positif yang signifikan antara motivasi petani terhadap pendapatan usahatani jamur merang melalui faktor produksi.

Berdasarkan uraian tersebut, permasalahan yang akan dikaji adalahpola kemitraan antara petani cabai merah dengan Binamitra Hortikultura Multiagro Makmur, hubungan antara karakteristik petani dengan motivasi petani cabai merah, dan hubungan motivasi dengan pendapatan petani cabai merah di Kecamatan Ambulu Kabupaten Jember, Jawa Timur.

Adapun tujuan penelitian adalah untuk mengetahui pola kemitraan antara petani cabai merah dengan Binamitra Hortikultura Multiagro Makmur, hubungan antara karakteristik petani dengan motivasi petani cabai merah, dan hubungan motivasi dengan pendapatan petani cabai merah di Kecamatan Ambulu Kabupaten Jember, Jawa Timur.

\section{METODE PENELITIAN}

Penelitian dilakukan di Kecamatan Ambulu Kabupaten Jember, Jawa Timur. Penentuan daerah penelitian berdasarkan metode penentuan wilayah yang disengaja (purposive method) dengan pertimbangan bahwa daerah tersebut merupakan daerah yang potensial untuk budidaya tanaman cabai merah. Metode yang digunakan dalam penelitian adalah metode deskriptif dan analitik. Metode pengambilan contoh yang digunakan adalah total sampling. Sampel penelitian adalah petani cabai merah di Kecamatan Ambulu yang bermitra dengan Multiagro Makmur,sejumlah 32 orang. Metode yang digunakan untuk mengumpulkan data yaitu, observasi, wawancara terstruktur, dan studi pustaka.

Pola kemitraan dianalisis secara deskriptif. Analisis berfungsi untuk mendeskripsikan pola kerja sama yang terjalin diantara petani cabai merah besar dengan Binamitra Hortikultura Multiagro Makmur serta memberikan suatu uraian mengenai pola dan mekanisme kerja sama kemitraan. Kemudian hasil uraian itu di bandingkan dengan pola kemitraan yang direkomendasikan oleh pemerintah yang terdiri atas pola inti plasma, pola subkontrak, pola dagang umum, pola keagenan, Kerjasama Operasional Agribisnis (KOA), pola kemitraan sistem pertanian kontrak dan pola kemitraan model vendor sehingga bisa diketahui kecenderungannya mengikuti salah satu pola kerja sama yang ada.

Teori motivasi yang digunakan dalam penelitian ini adalah teori 
harapan yang dikemukakan oleh Victor Vroom, yakni menggunakan pendekatan dengan analisis statistik dengan tabulasi skor melalui metode skala likert. Indikator-indikator untuk mengetahui motivasi petani cabai merah menggunakan skor meliputi:

A. Kesempatan yang ada dan akan berpengaruh dalam pencapaian harapan (expectancy) $\quad(7-$ 35)

B. Penilaian yang diberikan petani terhadap reward yang didapatkannya (valence) $(6-30)$

C. Reward/imbalan yang diterima oleh petani cabai merah sebagai hasil kerja yang telah dilakukan petani (Instrumentally)

$$
(3-15)
$$

Pendapatan petani cabai merah dihitung dari rumus:

$\mathrm{Pd}=\mathrm{TR}-\mathrm{TC}$

$\mathrm{Pd}=$ Pendapatan petani cabai merah

$\mathrm{TR}=$ Total penerimaan cabai merah $\mathrm{TC}=$ Total biaya produksi usaha tani cabai merah (Soekartawi, 1995)

Hubungan karakteristik petani (umur, pendidikan formal, luas penguasaan lahan, jumlah tanggungan keluarga, dan pengalaman usahatani)dengan motivasidan hubungan motivasi dengan pendapatan petani cabai merah dianalisis menggunakan Rank Spearman.Menurut
Supranto (2009), rumusnya sebagai berikut:

$$
r_{s}=1-\left(\frac{6 \sum d^{2}}{n\left(n^{2}-1\right)}\right)
$$

Keterangan:

$\mathrm{r}_{\mathrm{s}} \quad=$ koefisien korelasi Spearman

$\mathrm{d}=$ perbedaan setiap pasang rank

$\mathrm{n} \quad$ = jumlah pasangan rank

Penentuan kriteria pengambilan keputusan:

a. Probabilitas signifikansi $\leq 0,05$, maka $\mathrm{H}_{0}$ ditolak.

b. Probabilitas signifikansi $>0,05$, maka $\mathrm{H}_{0}$ diterima.

Untuk menentukan kekuatan hubungan antarvariable disajikan dalam Tabel 2 ..

Tabel 2. Interpretasi Koefisien

\begin{tabular}{cl} 
& Korelasi \\
\hline Interval nilai & \multicolumn{1}{c}{ Kekuatan hubungan } \\
\hline $0,00-0,199$ & Sangat rendah \\
$0,20-0,399$ & Rendah \\
$0,40-0,599$ & Sedang \\
$0,60-0,799$ & Kuat \\
$0,80-1,000$ & Sangat kuat \\
\hline
\end{tabular}

Sumber: Sugiyono, 2015

\section{HASIL DAN PEMBAHASAN}

Pola Kemitraan Antara Petani Cabai Merah dengan Binamitra Hortikultura Multiagro Makmur

Kemitraanyangdijalankanolehp etani cabai merahdiKecamatan Ambulu dengan Binamitra Hortikultura Multiagro Makmur termasuk dalam kemitraan subkontrak. Polakemitraansubkontrakmerupakan polakemitraan antara perusahaan 


\section{Jurnal Agritexts Volume 41 Nomer 2 Oktober 2017}

mitra usaha dengan kelompok mitra usaha yang memproduksi barang atau jasa yang diperlukan perusahaan mitra sebagai bagian dari produksinya (Sumardjo, 2004). PT Indofood memerlukan ketersediaan cabai merah sebagai bahan baku produknya sehingga Binamitra Hortikultura Multiagro Makmur berkewajiban untuk memasok cabai merah. Cabai merah diperoleh dari petani cabai merah yang telah bermitra. Adapun gambar terkaitdengan alur penyetoran, alur pembayaran, dan alur informasidalamkemitraan.

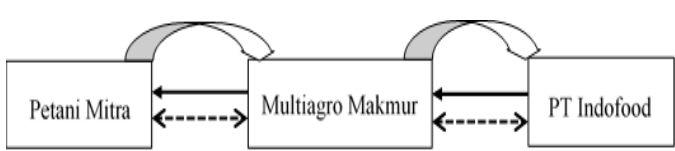

Gambar 1. Alur Penyetoran, Finansial, dan Informasi

Keterangan:

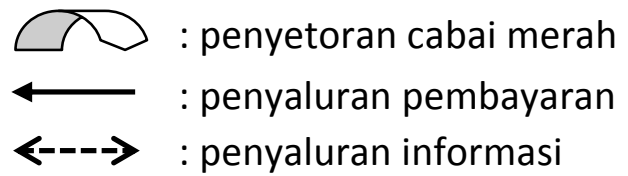

Gambar 1menjelaskan bahwa alur penyetoran dimulai dari petani yang memanen hasil produksinya kemudian menyetorkan kepada Binamitra Hortikultura Multiagro Makmur. Selanjutnya Binamitra Hortikultura Multiagro Makmur menyetorkan pada pihak PT Indofood. Pembayaran hasil produksi diberikan oleh PT Indofood kepada pihak Binamitra Hortikultura Multiagro Makmur kemudian pihak Binamitra Hortikultura Multiagro Makmur memberikan kepada petani. Kemudian penyaluran informasi terjadi dua arah, dari petani mitra ke Binamitra Hortikultura Multiagro Makmur kemudian ke pihak PT Indofood.

Binamitra Hortikultura Multiagro Makmur berperan untuk membimbing petani dalam melaksanakan kegiatan usahatani cabai merah. Hal tersebut dilakukan agar petani dapat menghasilkan cabai merah sesuai dengan yang diminta oleh PT Indofood sebagai perusahaan mitra. Binamitra Hortikultura Multiagro Makmur juga mempunyai kewajiban untuk menyampaikan informasi dari pihak PT Indofood secara jujur kepada petani.

Selain itu, pihak Binamitra Hortikultura Multiagro Makmur membeli cabai merah petani seharga Rp 9.000,00 per kilogram sesuai dengan perjanjian kontrak. Binamitra Hortikultura Multiagro Makmur dapat memberikan pinjaman kepada petani berupa saprodi, yaitu mulsa, bibit, pupuk, dan obat-obatan. Bagi petani yang mendapatkan pinjaman berkewajiban untuk membayarnya. Pembayaran dilakukan dengan cara memotong penerimaan hasil penjualan cabai merah. 


\section{Damayanti, Subekti, Sudarko, karakteristik petani,,,}

Hubungan Antara Karakteristik Petani dengan Motivasi Petani

Hasil analisis hubungan karak- petani cabai merah dijelaskan pada Tabel 4.

teristik petani dengan motivasi

Tabel4. Hubungan Karakteristik Petani dengan Motivasi Petani Cabai Merah yang di Kecamatan Ambulu Kabupaten Jember, Jawa Timur

\begin{tabular}{clcrll}
\hline No. & \multicolumn{1}{c}{ Karateristik Petani } & (rs) & \multicolumn{1}{c}{ Sig. } & \multicolumn{1}{c}{ Ket. } & Kekuatan Hub. \\
\hline 1. & Umur & 0,393 & $0,026^{*}$ & signifikan & Rendah \\
2. & Pendidikan formal & 0,363 & $0,041^{*}$ & signifikan & Rendah \\
3. & Luas penguasaan lahan & 0,390 & $0,027^{*}$ & signifikan & Rendah \\
4. & Jumlah tanggungan keluarga & 0,030 & 0,869 & tidak signifikan & Sangat rendah \\
5. & Pengalaman Usahatani & 0,237 & 0,192 & tidak signifikan & Sangat rendah \\
\hline
\end{tabular}

Keterangan: ${ }^{*}$ ) Signifikansi nyata taraf kepercayaan $95 \%$

Hasil analisis yang disajikan pada Tabel 4menjelaskan bahwa variabel yang berhubungan secara signifikan dengan motivasi petani cabai merah adalah variabel umur, pendidikan formal, dan luas penguasaan lahan sedangkan variabel yang memiliki hubungan secara tidak signifikan dengan motivasi petani cabai merah adalah variabel jumlah tanggungan keluarga dan pengalaman usahatani cabi merah. Berikut adalah penjelasan terkait dengan hubungan karakteristik petani cabai merah dengan motivasi petani cabai merah.

1. Umur

Berdasarkan Tabel 4 menunjukkan nilai rs 0,393, signifikansi 0,026 , maka terdapat hubungan yang signifikan dengan kekuatan rendah. Petani yang berumur tua memiliki motivasi yang tinggi untuk berusahatani cabai merah. Petani cabai merah mayoritas digolongan dalam usiaproduktif sehingga lebih termotivasi untuk berusahatani cabai merah. Petani yang produktif mempunyai banyak kebutuhan untuk meningkatkan kesejahteraan keluarganya sehingga lebih giat berusahatani cabai merah.

\section{Pendidikan Formal}

Berdasarkan Tabel 4 menunjukkan nilai rs 0,363, signifikansi 0,041 , maka terdapat hubungan yang signifikan dengan kekuatan rendah. Petani yang berpendidikan formal tinggi mempunyai motivasi tinggi untuk berusahatani cabai merah. Petani yang berpendidikan formal tinggi umumnya sadar untuk terus meningkatan penghidupan yang layak dengan memanfaatkan ilmu pengetahuan yang dimiliki kemudian diaplikasikan pada usahatani cabai merah. Menurut Mardikanto (1993), program khusus untuk pendidikan petani merupakan segi penting dari pendidikan untuk pembangunan 


\section{Jurnal Agritexts Volume 41 Nomer 2 Oktober 2017}

karena kemampuan petani dan keputusan-keputusanyang diambilnya mengenai pembangunan pertanian akan menentukan tingkat kecepatan pembangunan pertanian. Petani di Kecamatan Ambulu yang memiliki tingkat pendidikan formal yang tinggi biasanya menjadi panutan dalam berusahatani cabai merah.

3. Luas Penguasaan Lahan

Berdasarkan Tabel 4 menunjukkan nilai rs 0,390, signifikansi 0,027 , maka terdapat hubungan yang signifikan dengan kekuatan rendah. Petani yang memiliki lahan yang luas maka motivasinya tinggi untuk usahatani cabai merah. Petani yang memiliki lahan yang luas dan modal yang besar, ingin mencoba inovasiinovasi baru. Inovasi tersebut dapat meningkatkan produktivitas cabai merah. Peningkatan produktivitas tersebut diikuti dengan peningkatan pendapatan petani. Petani cabai merah mayoritas mempunyai luas lahan yang dapat dikategorikan rendah namun petani sudah tidak menggunakan teknologi tradisional. Petanisudah menggunakan alat pertanian modern dan semua hasil produksinya dijual.

4. Jumlah Tanggungan Keluarga

Berdasarkan Tabel 4 menunjukkan nilai rs 0,030, signifikansi 0,869 , maka terdapat hubungan yang tidak signifikan dengan kekuatan sangat rendah.Jumlah tanggungan keluarag bukan merupakan faktor yang dapat meningkatkan motivasi petani untuk berusahatani cabai merah melainkan tingginya pendapatan karna cabai merah adalah salah satu komoditas yang mempunyai nilai ekonomis tinggi.

5. Pengalaman Usahatani Cabai Merah

Berdasarkan Tabel 4 menunjukkan nilai rs 0,237 , signifikansi 0,192 , maka terdapat hubungan yang tidak signifikan dengan kekuatan sangat rendah.Petani cabai merah menjalankan usahataninya karena dirasa komoditas cabai merah adalah komoditas yang lebih menguntungkan dibandingkan dengan komoditas tembakau yang pernah mereka budidayakan sebelumnya sehingga usahatani cabai merah yang mereka jalankan bukan merupakan kegiatan usahatani yang turun temurun. Motivasi petani cabai merah dalam berusahatani cabai merah bukan karena lamanya pengalaman dalam melakukan usahatani melainkan karena kemudahankemudahan yang diperoleh saat mengikuti kemitraan sehingga petani akan terus meningkatkan motivasinya untuk berusahatani cabai merah.

\section{Hubungan Antara Motivasi dengan Pendapatan Petani Cabai Merah}

Keberhasilan suatu usahatani dapat dilihat dari pendapatan petani. Pendapatan usahatani cabai merah diperoleh dari total penerimaan 


\section{Damayanti, Subekti, Sudarko, karakteristik petani,נ,}

dikurangi total biaya yang dapatan petani di Kecamatan dikeluarkan selama proses produksi. Ambulu disajikan pada Tabel 5.

Total penerimaan ini berasal dari hasil produksi $(\mathrm{kg})$ cabai merah yang sudah dipanen dikalikan dengan harga jual (Rp) sesuai dengan perjanjian kontrak. Kegiatan usahatani cabai merah dapat dikatakan menguntungkan apabila penerimaan yang diperoleh petani lebih besar dari biaya produksi yang dikeluarkan. Sebaliknya, apabila kegiatan usahatani cabai merah dikatakan rugi apabila penerimaan yang diperoleh petani lebih kecil dibandingkan dengan biaya yang dikeluarkan satu kali musim tanam. Rata-rata pen-

Tabel 5. Rata-rata Pendapatan Petani Cabai Merah di Kecamatan Ambulu Kabupaten Jember, Jawa Timur

\begin{tabular}{ll} 
Rata-rata penerimaan & Rp 43.877.531,00 \\
Rata-rata biaya & Rp 23.904.236,00 \\
Rata-rata pendapatan & Rp 19.973.295,00 \\
\hline
\end{tabular}

Hubungan motivasi petani terhadap pendapatan usahatani cabai merah yang bermitra dengan Binamitra Hortikultura Multiagro Makmur di Kecamatan Ambulu dianalisi dengan korelasi Rank Spearman. Hasil analisis korelasi Rank Spearman (rs)dapat dilihat pada Tabel 6.

Tabel 6. Hubungan antara Motivasi dengan Pendapatan Petani Cabai Merah di Kecamatan Ambulu Kabupaten Jember, Jawa Timur

\begin{tabular}{lcccc}
\hline \multicolumn{1}{c}{ Variabel } & $\mathbf{r}_{\mathrm{s}}$ & Sig. & Ket. & Kekuatan Hubungan \\
\hline Motivasi & 0,366 & $0,039^{*}$ & signifikan & Rendah \\
\hline Pendapatan & & & &
\end{tabular}

Berdasarkan Tabel 6 menunjukkan nilai rs 0,366, signifikansi 0,039 , maka terdapat hubungan yang signifikan dengan kekuatan rendah. Petani yang memiliki motivasi tinggi untuk usahatani cabai merah maka memperoleh pendapatan yang tinggi.

Bermitra merupakan salah satu strategi pemasaran yang dipilih oleh petani karena cabai merah merupakan komoditas yang harga jualnya fluktuatif.Untuk memini- malisir resiko tersebut maka petani bermitra dengan Binamitra Hortikultura Multiagro Makmur. Harga jual senilai Rp 9.000,00 per kilogram yang telah disepakati dirasa oleh petani cabai merah telah menguntungkan sehingga dalam hal pemasaran petani tidak perlu mencari strategi lagi sehingga petani akan terus termotivasi untuk usahatani cabai merah. 


\section{Jurnal Agritexts Volume 41 Nomer 2 Oktober 2017}

Komoditas cabai merah juga tergolong komoditas yang mudah busuk. Kemitraan adalah salah satu strategi petani untuk mengatasi hal tersebut. Seluruh hasil produksi cabai merah sudah pasti dibeli oleh Binamitra Hortikultura Multiagro Makmur sehingga petani tidak mengalami kerugian yang disebabkan oleh susutnya hasil produksi.

Biaya usahatani cabai merah yang diperlukan cukup besar. Petani yang bermitra mendapatkan fasilitas berupa sarana produksi. Sarana produksi tersebut dapat diperoleh di kios Binamitra Hortikultura Multiagro Makmur. Petani cabai merah boleh menggunakan sarana produksi yang dibutuhkan kemudian pembayarannya dilakukan dengan cara memotong penerimaan dari hasil penjualan cabai merah. Fasilitas yang diberikan mampu mencukupi beberapa sarana produksi meliputi, benih Imola F1, pupuk, obat-obatan, mulsa, dan polybag sehingga produktivitasnya meningkat. Peningkatan produktivitas akan meningkatkan pendapatan petani sehinggaakan lebih termotivasi untuk berusahatani cabai merah.

\section{KESIMPULAN DAN SARAN}

\section{Kesimpulan}

Berdasarkan uraian yang telah dijelaskan, disimpulkan bahwa. kemitraanyangdijalankanolehpetanicab ai merah dengan Binamitra
Hortikultura Multiagro Makmur termasuk dalam kemitraan subkontrak. Terdapat hubungan secara signifikan antara umur, pendidikan formal, dan luas pengusaan lahan dengan motivasi petani cabai merah sedangkan jumlah tanggungan keluarga dan pengalaman usahatani terdapat hubungan secara tidak signifikan dengan motivasi petani cabai merah serta terdapat terdapat hubungan secara signifikan antara motivasi petani dengan pendapatan petani cabai merah yang bermitra dengan Binamitra Hortikultura Multiagro makmur di Kecamatan Ambulu Kabupaten Jember, Jawa Timur.

\section{Saran}

Disarankan untuk perusahaan mitra agar meningkatkan fasilitasfasilitas yang dimiliki sehingga petani cabai merah semakin tertarik untuk menjalin kemitraan dan juga semakin termotivasi dalam budidaya cabai merah.

\section{DAFTAR PUSTAKA}

Dinas Pertanian Kabupaten Jawa Timur. (2016). Data Luas Panen, Produksi, dan Produktivitas Berdasarkan Kecamatan di Kabupaten Jember Tahun 2015. Jember: Disperta

Fauzi, Nurul Fathiyah. (2009). Pengaruh Motivasi Petani Jamur Merang (Volvariella Volvacene) Terhadap Peningkatan Penda- 


\section{Damayanti, Subekti, Sudarko, karakteristik petani,נ,}

patan Usahatani Jamur Merang Di Kabupaten Jember. Skripsi tidak dipublikasikan.Fakultas Pertanian Universitas Jember. Jember.

Hutabarat, B. dan Rahmanto, B. (2002). Dimensi Oligopsonistik Pasar Domestik Cabai Merah. Pusat Penelitian dan Pengembangan Sosial Ekonomi Pertanian. 4 (1)

Indraningsih, Kurnia Suci, Ashari, dan Supena Friyanto. (2008), Strategi Pengembangan Model Kelembagaan kemitraan Agribisnis Hortikultura di Bali. Pusat Analisis Sosial Ekonomi dan Kebijakan Pertanian. 8(2): 1-18

Mardikanto, Totok. (1993). Penyuluhan Pembangunan Pertanian. Surakarta: Sebelas Maret University Press

Moekijat. (1999). Dasar-Dasar Motivasi. Bandung: Pionir Jaya

Ningtias, Rahayu. (2015). Efektivitas Pola Kemitraan PT Indofood dan Dampak Sosial Ekonomi Petani Cabai Merah Besar di Desa Andongsari Kecamatan Ambulu Kabupaten Jember. Skripsi tidak dipublikasikan. Universitas Jember. Jember

Nurdin. (2011). Teknologi dan Perkembangan Agribisnis Cabai di Kabupaten BoalemoProvinsi Gorontalo. Litbang Pertanian. 30(2): 55-65
Prasilia, Dewi Asadina. (2013). Hubungan Antara Karakteristik Sosial Ekonomi Petani dengan Motivasi Petani dalam Budidaya Bawang Merah di Kecamatan Sanden Kabupaten Bantul. Skripsi tidak dipublikasikan. Universitas Sebelas Maret.Solo.

Primadesi, Febriana. (2010). Motivasi Petani dalam Budidaya Tanaman Buah Naga (Hylocereus Sp.) di Kecamatan Bendosari Kabupaten Sukoharjo. Skripsi tidak dipublikasikan. Universitas Sebelas Maret. Solo

Setiadi. (2000). Bertanam Cabai. Jakarta: Penebar Swadaya

Siagian, Sondang. (2004). Teori Motivasi dan Aplikasinya. Jakarta : PT Rineka Cipta.Soekartawi. (1995). Analisis Usaha Tani. Jakarta. UI-Press.

Soekartawi. (1995). Analisis Usaha Tani. Jakarta. UI-Press

Sugiyono dan Agus Susanto. (2015). Cara Mudah Belajar SPSS dan Lisrel (Teori dan Aplikasi Untuk Analisis Data Penelitian). Bandung: Alfabeta

Sumardjo, Darmono, dan Jaka S. (2004). Teori dan Praktik Kemitraan Agribisnis. Jakarta: Penebar Swadaya.

Supranto, J. (2009). Statistik Teori dan Aplikasi. Jakarta: Erlangga 